\title{
巨大分子系の量子化学計算と創薬研究への応用
}

\author{
北浦 和 夫
}

\section{Large Scale Quantum Chemical Calculation for Drug Discovery}

\author{
Kazuo KiTAURA \\ Graduate School of Pharmaceutical Sciences, Kyoto University, 46-29 Yoshida-Shimoadachi-cho, \\ Sakyo-ku, Kyoto 606-8501, Japan
}

(Received April 6, 2011)

\begin{abstract}
Due to the increase in computer power and the development of computational methods, it becomes possible to perform quantum mechanical calculations of very large molecules such as proteins that were previously exclusively treated with classical force field methods. We have developed the fragment molecular orbital (FMO) method aimed at biomolecular applications. One of the important applications of the method is in structure-based drug design because it provides accurate descriptions of various non-bonded interactions between a protein and its ligand. In this article, the FMO method will be described as well as its applications to the analysis of protein-ligand binding.
\end{abstract}

Key words — fragment molecular orbital method; drug design; protein-ligand interaction

\section{1. はじめに}

1990 年代から大規模分子・分子集合系の量子化 学計算法の開発が活発に進められている。 それらの 大部分は，系を小さな部分（フラグメント）に分割 して計算し，フラグメントのエネルギーやその他の プロパティを用いて全系の対応するプロパティを求 める方法である。このようなアプローチの歴史は古 く 1960 年代から始まっているが，最近になって新 しい様々な方法が提案され，数千-数万原子からな るタンパク質のような巨大分子に適用できる実用的 な方法がいくつか出現してきた。このような計算法 の発展とコンピュータの性能向上が相俟って, 従来 は古典的・経験的な力場計算 (molecular mechanics；MM）での夕可能であったタンパク質やタンパ ク質ーリガンド複合体の構造やエネルギーを量子論 的に計算することが可能になり創薬研究への応用が 進んでいる. ${ }^{1)}$ 本稿では，私たちが開発している巨 大分子系の量子化学計算法であるフラグメント分子 軌道 (fragment molecular orbital; FMO) 法年につ

京都大学大学院薬学研究科 ( $\bar{T} 606-8501$ 京都市左京区 吉田下阿達町 46-29)

e-mail:kkitaura@pharm.kyoto-u.ac.jp

本総説は, 日本薬学会第 130 年会シンポジウム SS03

で発表したものを中心に記述したものである。
いて解説し，ドラッグデザインへの応用について述 ベる.

\section{2. フラグメント分子軌道法}

2-1. 巨大分子系の量子化学計算 Structurebased drug design (SBDD) では, タンパク質とリ ガンドの結合構造と分子間相互作用に関する知見が 基本となる。量子化学計算 (ab initio MO 計算) は, 分子の構造，エネルギーや分子間相互作用の計算法 として高い信頼性をもつことはよく知られている. しかし，最も簡便なハートリー・フォック（Hartree-Fock; HF) や密度汎関数理論（density functional theory；DFT）計算でも系のサイズの 3 乗程 度に比例して計算時間が増大するため, タンパク質 のような数千-数万原子からなる巨大分子の計算は 実際的に困難である。さらに， $\mathrm{CH} / \pi$ や $\mathrm{CH} / \mathrm{O}$ 相 互作用などタンパク質のリガンド結合で頻繁に現れ る弱い非結合相互作用を適切に記述するためには電 子相関理論を用いる必要があるが，この最も簡便な 理論である Møller-Plesset の 2 次摂動論（second order Møller-Plesset perturbation theory; MP2) で さえも計算時間は系のサイズの 5 乗に比例して増大 するためよりいつそう困難となる，最近，必要な計 算資源の増大が系のサイズに比例する程度に収ま り，あわせて並列コンピュータによる効率的な計算 
を行うことができる計算法がいくつか開発され，巨 大分子系の量子化学計算が可能になってきた．この ような方法の大部分は系を小さなフラグメントに分 割して計算する方法であり, ${ }^{3)}$ 私たちが提案した FMO 法もそのひとつである.

2-2. 分子のフラグメント分割 FMO 法では, Fig. 1 の例で示すように，分子を $N$ 個のフラグメ ントに分割する。一般に，共有結合の切断は $\mathrm{sp}^{3}$ 炭 素の結合などフラグメント間で電子の非局在化が少 ない位置で行う。ポリペプチドの場合は， $\mathrm{C}_{\alpha}$ 原子 とカルボニル炭素の間の結合を切断してアミノ酸残 基単位で分割することが普通である。ただし，フラ グメントサイズが小さすぎると誤差（ab initio MO 法の結果との差）が大きくなるので，グリシンは隣 のアミノ酸残基に合体させることが多い。

フラグメント分割法のほとんどは，共有結合を切 断した原子の原子価を満たすために水素原子などで キャップする．フラグメントにキャップ原子を導入 すると元の分子の部分とは異なるので，部分をそれ に似たモデル分子で近似することになる。これに対 して，FMO 法は余分な原子や結合を導入すること なく，元の系に含まれる原子核と電子のみを用いる.

Figure 2 のエタンの例で示すように, FMO 法のフ ラグメント分割では，結合電子対を破壊しない形で 結合を切り離し，8 電子からなるフラグメント（f： 1) と 10 電子からなるフラグメント (f : 2) を作る. このような電子の割り振りを行うと, $\mathrm{f}: 1$ は形式 的に+1, $\mathrm{f}: 2$ は-1 の電荷を持つことになるが, 電子の割り振りに対応して共有結合を切り離した原 子（bond-detached atom; BDA）の核電荷を分割す ることで，フラグメントの形式電荷を元の分子中の 対応する部分の電荷と一致させる（Fig. 2 の例で

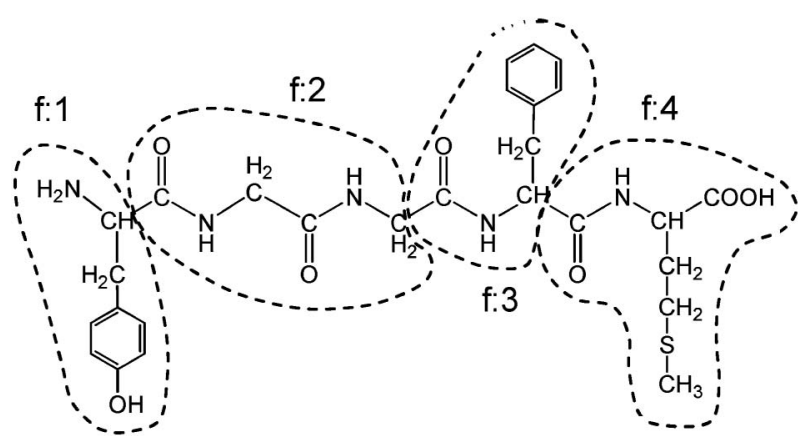

Fig. 1. Typical Fragmentation Scheme of Polypeptide in FMO Calculations
は，炭素原子核の +6 の電荷を +5 と +1 に分割).

2-3. フラグメントの分子軌道 FMO 法は, 上記のように定義したフラグメント単量体（以下, 単にモノマーという）とフラグメント 2 量体（ダイ マー）について，ほぼ通常の ab initio MO 法と同 様の計算を行うことにより，それぞれの分子軌道を 求める（以下では，簡単のために HF 法について述 べる），通常の $\mathrm{ab}$ initio MO 計算との相違点は，1） BDA の基底関数を分割してフラグメントに割り振 ること，2）周りのフラグメントが及ぼす静電ポテ ンシャルの下で MO を求めることである.

BDA の基底関数の割り振りは，Fig. 3 で示すよ うに, $\mathrm{f}: \mathrm{I}$ と $\mathrm{f}: \mathrm{I}+1$ フラグメントを分ける BDA の基底関数を混成軌道に変換して，切り離した結合 の相手原子の方向を向いた混成軌道を $\mathrm{f}: \mathrm{I}+1$ の基 底関数に，残りのすべての混成軌道を $\mathrm{f}: \mathrm{I}$ に割り 振る。当然， $\mathrm{f}: \mathrm{I}$ と $\mathrm{f}: \mathrm{I}+1$ に属するその他の原子 の基底関数は，それぞれのフラグメントの MO の 基底として用いる。

モノマーIの MO は，このような基底関数を用 いて，他のモノマーからの静電ポテンシャル $V^{I}(\mathbf{r})$,

$$
V^{I}(\mathbf{r})=\sum_{K \notin I}\left\{\sum_{a \in K} \frac{-Z_{a}}{\left|\mathbf{r}-\mathbf{R}_{a}\right|}+\int \frac{\rho^{K}\left(\mathbf{r}^{\prime}\right)}{\left|\mathbf{r}-\mathbf{r}^{\prime}\right|} d \mathbf{r}^{\prime}\right\}
$$

を加えた 1 電子ハミルトニアンを用いて Fock 方程 式を解いて MO を求める。ここで， $a$ は原子， $\mathbf{R}_{a}$ はその座標, $\rho^{K}(\mathbf{r})$ はモノマー $K$ の電子分布を示 す。モノマーの MO は環境静電ポテンシャルによ り変化するので，すべてのモノマーがお互いに無撞 着になるまで繰り返し計算を行う。ダイマーの MO

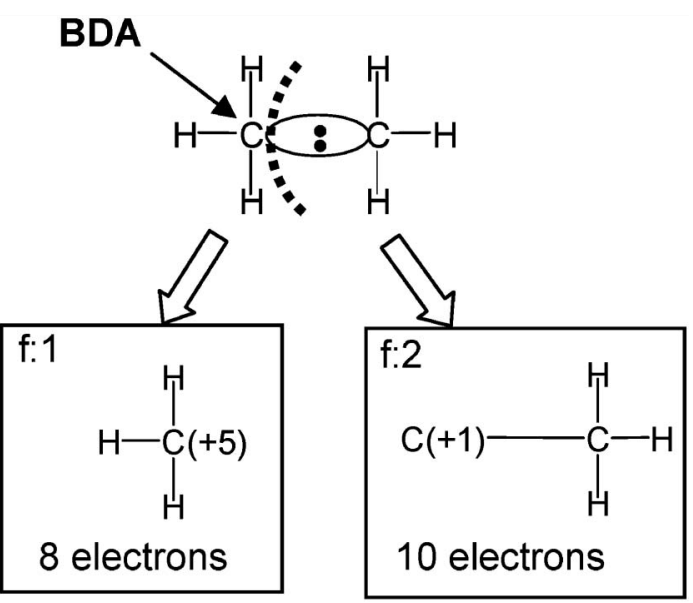

Fig. 2. Electoron and Nuclear Charge Division along Fractionated Fragments 


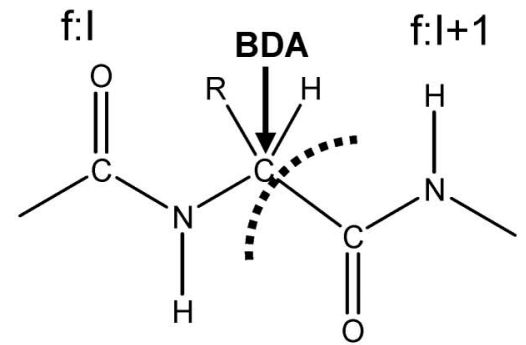

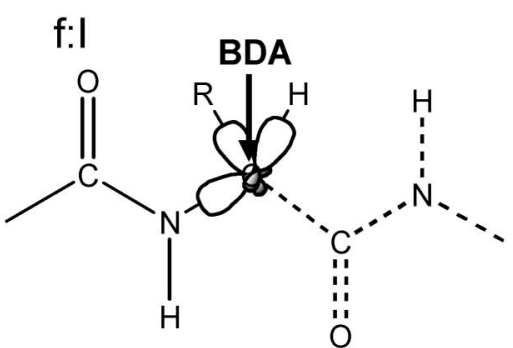

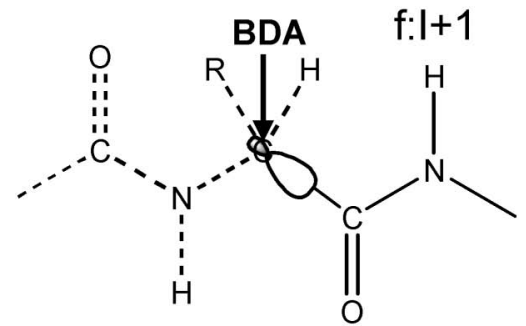

Fig. 3. Partition of BDA Hybrid Orbitals along Detached Bond

も同様にして求めるが，モノマーの場合と異なつ て, 環境静電ポテンシャルは先に求めたモノマーの 電子分布を用いて計算する（繰り返し計算は行わな ().

FMO 法では， $N$ 個のモノマーと $N(N-1) / 2$ 個 のダイマーの MO 計算をしなければならないが, 実際の計算では，距離が離れたフラグメントからの 静電ポテンシャルを点電荷で近似したり，距離が離 れたモノマーから構成されるダイマーのエネルギー をモノマー間の静電相互作用エネルギーで近似する などにより，精度をほとんど落とすことなく計算量 を大幅に減少させて高速計算を実現している.

2-4. 全エネルギーとフラグメント間相互作用エ ネルギー モノマーIとダイマーIJの MO が求 まると，それらの全エネルギー $E_{\mathrm{I}}$ と $E_{\mathrm{IJ}}$ を用い て，全系の全エネルギーを次式で計算する。

$$
E=\sum_{I}^{N} E_{I}+\sum_{I>J}^{N}\left(E_{I J}-E_{I}-E_{J}\right)
$$

Equation（2)では，モノマーとダイマーのエネル ギーのみを用いているが，これにトリマーの項を加 えてより高精度化した方法も提案されている. ${ }^{2)}$
れらは，それぞれ FMO2 法と FMO3 法と呼ばれて いるが，本稿では後者には触れないので，前者を単 にFMO 法と呼ぶ.

ここまで電子状態計算の基本である $\mathrm{HF}$ 理論の FMO 法（FMO-HF 法）について述べてきたが, MP2 電子相関理論の FMO 法（FMO-MP2 法）は, 単純にモノマーとダイマーの電子相関エネルギー $\Delta E^{\mathrm{corr}}$ を求めて，それぞれの HF エネルギーに加え て全エネルギーとし，

$$
E_{x}^{\text {corr }}=E_{x}+\Delta E_{x}^{\text {corr }} \quad(x=I \text { or } I J)
$$

Equation (2) 中の $E_{x}$ をこれらで置き換えるだけで よい.

さて，ここで FMO 法から得られるフラグメント 間相互作用エネルギー（pair interaction energy, PIE と呼ぶ）について説明する. Eq. (2)の第 2 項は, 一見フラグメント間の相互作用エネルギーを表して いるように見える。しかし，先に述べたように，モ ノマーとダイマーの全エネルギーは，それぞれの内 部エネルギーに加えて他のモノマーの静電場による 静電ポテンシャルを含んでいるので，このままでは 相互作用エネルギーではない。そこで， $E_{x}$ から環 境静電ポテンシャルエネルギーを引いた内部エネル ギー $E_{x}^{\prime}$,

$$
E_{x}^{\prime}=E_{x}-\operatorname{Tr}\left(\mathbf{D}^{x} \mathbf{V}^{x}\right)
$$

を導入して Eq. (2)を書き換えると次式となる.

$$
E=\sum_{I} E_{I}^{\prime}+\sum_{I>J}\left(E_{I J}^{\prime}-E_{I}^{\prime}-E_{J}^{\prime}\right)+\sum_{I>J} \operatorname{Tr}\left(\Delta \mathbf{D}^{I J} \mathbf{V}^{I J}\right)
$$

ここで, $\mathbf{D}^{x}$ は $x$ の電子密度行列で,$\Delta \mathbf{D}^{I J}$ はダイ マーとモノマーの電子密度行列の差 $\Delta \mathbf{D}^{I J}=\mathbf{D}^{I J}-\mathbf{D}^{I}$ 一 $\mathbf{D}^{J}$ である。また， $\mathbf{V}^{I J}$ はダイマー $I J$ にかかる環 境静電ポテンシャルである. Equation (5)の第 1 項 は，環境静電ポテンシャルにより分極したモノマー のエネルギーである．第 2 項と第 3 項はフラグメン ト I $J$ の相互作用エネルギーに関連したエネル ギーなので，これらをまとめて $\Delta E_{I J}$ とし，これを PIE と定義する

$$
\Delta E_{I J}=\left(E_{I J}^{\prime}-E_{I}^{\prime}-E_{J}^{\prime}\right)+\operatorname{Tr}\left(\Delta \mathbf{D}^{I J} \mathbf{V}^{I J}\right)
$$

Equation（6) は HF 理論の場合であるが，一般的に は，これに電子相関エネルギーを含めて次式で PIE を定義する。

$$
\begin{aligned}
\Delta E_{I J}= & \left\{\left(E_{I J}^{\prime}-E_{I}^{\prime}-E_{J}^{\prime}\right)+\operatorname{Tr}\left(\Delta \mathbf{D}^{I J} \mathbf{V}^{I J}\right)\right\} \\
& +\left(E_{I J}^{\text {corr }}-E_{I}^{\text {corr }}-E_{J}^{\text {corr }}\right)
\end{aligned}
$$


タンパク質とリガンドの複合体の計算で, タンパ ク質をアミノ酸残基を単位としてフラグメントに分 割すると，PIE はタンパク質の個々のアミノ酸残基 とリガンド間の相互作用エネルギーとなる.

\section{3. タンパク質とリガンドの相互作用解析}

3-1. 構造モデリングと計算法免疫抑制剤で ある $\mathrm{fk} 506$ と、これを含めた 4 種のリガンドと fk506 結合タンパク質（FKBP）との複合体 (Fig. 4) について FMO 計算を行い，タンパク質とリガンド の分子間相互作用を解析した. ${ }^{4)}$ 構造モデルは，複 合体構造の PDB 構造デー夕をもとに, 標準解離状 態を仮定して各アミノ酸残基に水素原子を付加し, それらの位置を力場で最適化した。 ついで，リガン ドとこれから $5 \AA$ 以内にあるアミノ酸残基を取り 出し, 未端を水素原子でキャップしたモデル複合体 を作り, リガンドの全原子とリガンドと水素結合し ているアミノ酸残基の水素原子の位置を FMO-HF/ $3-21 \mathrm{G}$ 計算で最適化した。この最適化座標を用い て，全系を FMO-MP2/6-31G*レベルでエネルギー

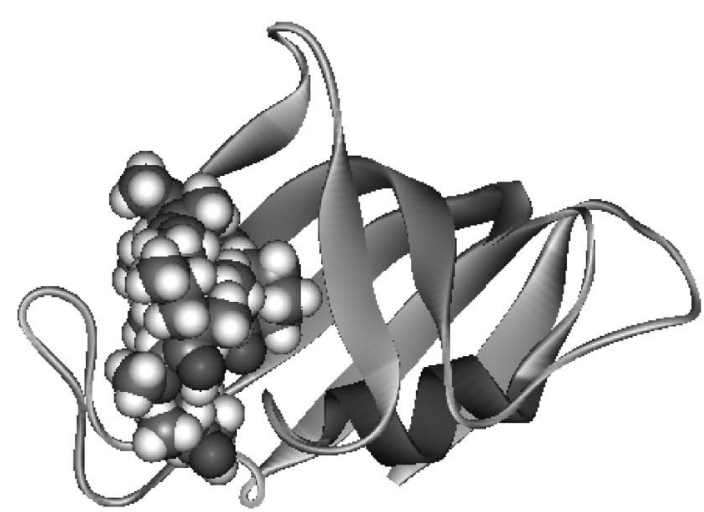

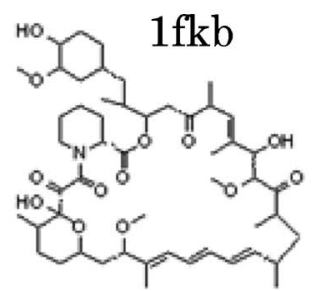

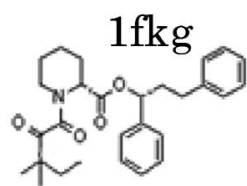

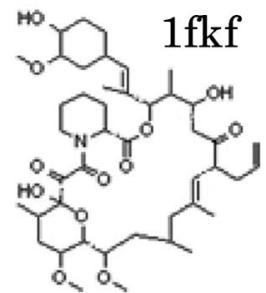

$1 \mathrm{fki}$
Fig. 4. Structure of FKBP-fk506 Complex (PDB : 1fkf) and Chemical Structures of Ligands

The ligand is denoted by the PDB code of its complex with FKBP.
を計算した。

3-2. 各アミノ酸残基とリガンドの相互作用エネ ルギーアミノ酸残基とリガンドの PIE とリガ ンドの結合構造を Fig. 5 に示す。フラグメント分 割は $\mathrm{C}_{\alpha}-\mathrm{C}=\mathrm{O}$ の $\mathrm{C}_{\alpha}$ 位で行ったため, $I$ 番目のア ミノ酸残基の $\mathrm{C}=\mathrm{O}$ は $I+1$ 番目のフラグメントに アサインされていることに注意して欲しい。このよ うなフラグメントを通常のアミノ酸残基と区別する ために，ここでは残基番号の前に＃記号をつけて表 す。ここで取り上げた 4 つのリガンド（PDB コー ドで呼ぶ）は，1fkb, 1fkf, 1fkg, 1fki の順に結合自 由エネルギーが小さくなることが分かっている（次 節参照)。PIEの和は，それぞれ，-159.2，一 $139.6,-97.6,-93.3 \mathrm{kcal} / \mathrm{mol}$ (負符号は安定化相 互作用を示す）であり，結合自由エネルギーとよい 相関がある。Tyr\#26，Val\#55，Tyr\#82 が4つのリ ガンドで共通して強い相互作用をもつことから，こ れらがリガンドの結合に重要な役割を果たしている ことが分かる。このことは構造（Fig. 5b）から推 定できることであるが，PIEによりこれらの相対的 な重要性を知ることができる、Val\#55, Tyr\#82 と リガンドの相互作用（水素結合）は，4つのリガン ドでほぼ同じ強さであるが，Tyr\#26 の相互作用は 結合が強いリガンド（1fkb と $1 \mathrm{fkf} ）$ では弱い分散 相互作用であるのに対して，結合が弱いリガンド （1fkg と 1fki）では HF 成分の寄与があることか ら, 水素結合が形成されることを示唆している。 一 方, 強いリガンドは弱いリガンドにはみられない Asp\#37 との強い水素結合が見られる。最も強い $1 \mathrm{fkb}$ では，これに加えて大きな Glu\#54 との相互作 用が存在する。構造からも 4 つのリガンドのうち $1 \mathrm{fkb}$ のみがこの残基と相互作用していることがわ かる.

FMO 計算から得られる PIE から，上記のように 結合に関与している各アミノ酸残基とリガンドとの 相互作用の性質と強さがわかるので, リガンドの最 適化設計において有用な知見となるだろう。さら に，相互作用の性質をより詳細に知りたい場合は， PIE を静電，交換反発，電荷移動エネルギーなどの 成分に分割するすることもできる. ${ }^{5}$

3-3. 結合自由エネルギーと溶媒効果 水溶液 中ではタンパク質とリガンドの結合に及ぼす溶媒効 果が大きい。結合自由エネルギーに対する溶媒和効 
a

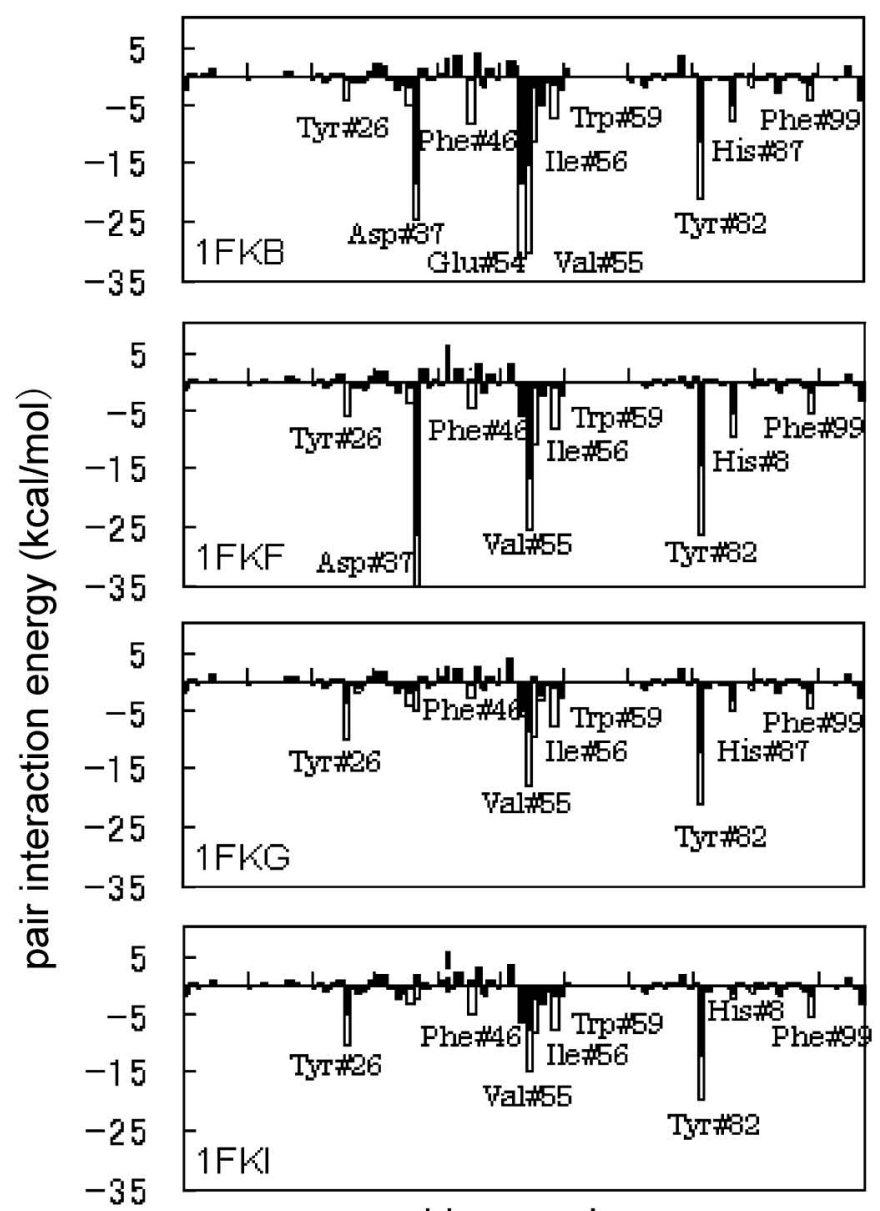

$\mathrm{b}$

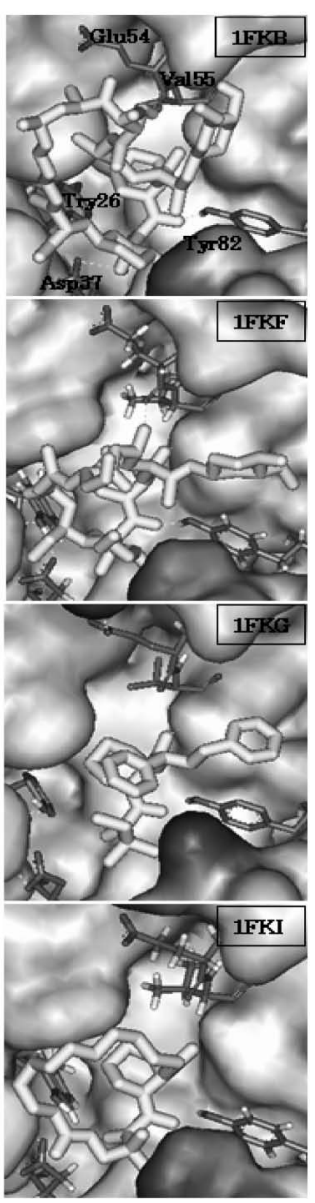

residue number

Fig. 5. Pair Interaction Energy (PIE) between Amino Acid Residue of FKBP and Ligand (a) and Binding Mode of Ligand (b) The filled and empty bars indicate HF and dispersion energy components, respectively.

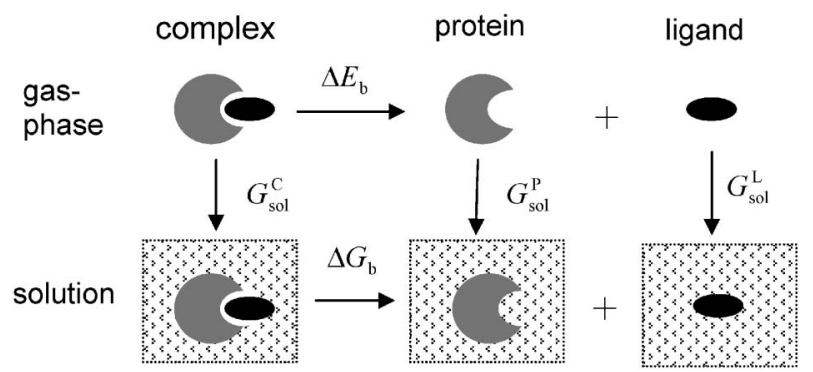

Fig. 6. Thermochemical Cycle Used in Calculations of Binding Free Energy in Solution

果は，Fig. 6 に示す熱力学サイクルで評価されるこ とが多い。これに従って結合自由エネルギーは次式 で計算できる.

$$
\Delta G_{\mathrm{b}}=\Delta G_{\mathrm{b}}^{\mathrm{gas}}+\left(G_{\mathrm{sol}}^{\mathrm{C}}-G_{\mathrm{sol}}^{\mathrm{L}}-G_{\mathrm{sol}}^{\mathrm{P}}\right)-T \Delta S
$$

第 1 項は気相での結合自由エネルギー，第 2 項は複 合体形成に伴う（部分）脱溶媒和エネルギー，第 3
項は配置エントロピーの項である，第 3 項は，複合 体，タンパク質やリガンドが複数のコンフォメーシ ヨンをとることからくるエントロピーの寄与である が, 本研究ではこの項を無視した.

気相の結合自由エネルギー $\Delta G_{\mathrm{b}}^{\mathrm{gas}}$ は次式で評価 した.

$$
\Delta G_{\mathrm{b}}^{\text {gas }}=\Delta E_{\mathrm{b}}+\Delta G_{\mathrm{vib}}
$$

$\Delta E_{\mathrm{b}}$ は気相での結合エネルギーで, 次のように計 算した。

$$
\begin{aligned}
& \Delta E_{\mathrm{b}}=E^{\mathrm{C}}-E^{\mathrm{P}}-E^{\mathrm{I}}=\Delta E_{\text {int }}+\Delta E_{\text {def }}^{\mathrm{L}} \\
& \Delta E_{\text {int }}=E^{\mathrm{C}}-E^{\mathrm{P}}-E^{\mathrm{L}(\mathrm{C})} \\
& \Delta E_{\mathrm{def}}^{\mathrm{L}}=E^{\mathrm{L}(\mathrm{C})}-E^{\mathrm{L}}
\end{aligned}
$$

$E^{\mathrm{C}}$ は複合体の全エネルギー, $E^{\mathrm{P}}$ は孤立したタンパ ク質の全エネルギーである。 $E^{\mathrm{L}(\mathrm{C})}$ はリガンドが複 合体中の構造をとるときの全エネルギーで， $E^{\mathrm{L}}$ は 孤立状態の構造でのリガンドの全エネルギーであ 
る.両者の差 $\Delta E_{\mathrm{def}}^{\mathrm{L}}$ は構造変形エネルギーである. 複合体の形成によりタンパク質の構造も変化する が，この変形エネルギーは評価することが難しいた め，一連の複合体で一定であると仮定した．複合体 形成に伴う溶質の自由エネルギー変化は調和振動子 近似で評価した。

$$
\Delta G_{\mathrm{vib}}=G_{\mathrm{vib}}^{\mathrm{C}}-G_{\mathrm{vib}}^{\mathrm{P}}-G_{\mathrm{vib}}^{\mathrm{L}}
$$

振動自由エネルギー $G_{\mathrm{vib}}$ は，複合体，タンパク質 とリガンドすべて力場で最適化した構造で振動解析 を行い, $298 \mathrm{~K}$ の值を求めた.

溶媒和自由エネルギーは, PB/SA (PoissonBoltzmann/surface area） モデル6)で計算した．PB/ $\mathrm{SA}$ の溶媒和自由エネルギーは次式で与えられる.

$$
G_{\text {sol }}=G_{\text {sol }}^{\text {ele }}+G_{\text {sol }}^{\text {nonpolar }}
$$

$G_{\text {sol }}^{\text {ele }}$ は溶質分子と溶媒の静電相互作用エネルギーで, $G_{\text {sol }}^{\text {nonpolar }}$ は溶質分子と溶媒の van der Waals 相互作 用や空孔形成エネルギーなど $G_{\text {sol }}^{\text {ele }}$ 以外のすべてを 含み, 溶媒接触表面積 (solvent accessible surface area; SA）の 1 次関数で近似される. ${ }^{7)}$

$$
G_{\text {sol }}^{\text {nonpolar }}=0.00682 \times \mathrm{SA}+0.80
$$

ここで，エネルギーの単位は $\mathrm{kcal} / \mathrm{mol} ， \mathrm{SA}$ の単位 は $\AA^{2}$ である。

上述の計算法で求めた結合自由エネルギーを $\mathrm{Ta}-$ ble 1 に示す。計算値は実験値に比べて最大 $7.2 \mathrm{kcal}$ /mol の過大評価となり，残念ながらリガンドの結 合親和力の順序の再現にも失敗した。しかし，気相 での大きな結合エネルギー $(-70.1--103.9 \mathrm{kcal} /$ $\mathrm{mol})$ が，脱溶媒和ペナルティ $\Delta G_{\mathrm{sol}}$ を考慮するこ とで実験值と同じオーダーとなった.

以上の結果が示すように，現状では量子化学計算 と溶媒の連続誘電体モデルを組み合わせても，結合 自由エネルギーを満足できる精度で計算することは

\begin{tabular}{|c|c|c|c|c|c|c|}
\hline \multirow{2}{*}{ ligand } & \multicolumn{2}{|c|}{$\Delta G_{\mathrm{b}}^{\text {gas }}$} & \multicolumn{2}{|c|}{$\Delta G_{\mathrm{sol}}$} & \multirow{2}{*}{$\begin{array}{l}\Delta G_{\mathrm{b}} \\
\text { (calc) }\end{array}$} & \multirow{2}{*}{$\frac{\Delta G_{\mathrm{b}}}{(\mathrm{expt})} *$} \\
\hline & $\Delta E_{\mathrm{b}}$ & $\Delta G_{\mathrm{vib}}$ & $\Delta G_{\text {sol }}^{\text {ele }}$ & $\Delta G_{\text {sol }}^{\text {nonpolar }}$ & & \\
\hline $1 \mathrm{fkb}$ & -103.9 & 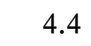 & 95.4 & - & 4 & \\
\hline $1 \mathrm{fkf}$ & -102.2 & 11.2 & 01.0 & -7.0 & -16.4 & -12.8 \\
\hline $1 \mathrm{fkg}$ & -70.1 & -8.1 & 69.9 & -6.1 & -14.4 & -10.9 \\
\hline $1 \mathrm{fki}$ & -71.3 & -1.6 & 62.0 & -5.7 & -16.7 & -9.5 \\
\hline
\end{tabular}

Table 1. Calculated Binding Free Energy (kcal/mol) of FKBP Ligand

* The experimental binding free energies converted from the inhibition constants. $^{8)}$
困難であり，今後溶媒和エネルギーの高精度な評価 法が必用であることが明らかである.

\section{FMO 法の計算プログラム}

FMO 計算が可能な $a b$ initio MO 計算プログラム として, GAMESS , ${ }^{9)}$ ABINIT-MP10) と PAICS ${ }^{11)}$ が公開されている。これらのプログラムは利用許諾 を得て無料で使用できる. FMO 計算の入力デー夕 作成は，分子の分割の情報や BDA の基底関数の割 り振りなどの指定が必要でかなり面倒である。ま た，出力が膨大になるため計算結果の整理も容易で ない。これらの負担を軽減するために，FMO 計算 のためのプリ・ポスト処理が行えるプログラムが開 発され公開されている。分子モデリングソフト Facio ${ }^{12)}$ は，GAMESS によるFMO 計算のためのプ リ・ポスト処理ができる。BioStation ${ }^{10)}$ と Paics View ${ }^{11)}$ はそれぞれ ABINIT-MP と PAICS 用であ る。これらのプログラムにより，PDB の構造デー 夕を用意すれば，FMO 計算のための入力データの 作成から，計算結果の可視化までを容易に行える.

FMO 法の計算は，大きな分子を計算する代わり に多数の小さな“分子”を計算することに相当する が，これらはほぼ独立に計算できるために並列計算 が容易であり，最近著しく性能が向上しているマル チコア計算機を最大限に活用できる，上記の FMO 計算プログラムによると，小・中規模から大規模並 列計算まで効率よく実行することができる．FMO 計算の計算時間の目安を示すと，約 5000 原子から なるタンパク質の HF 法（6-31G*基底関数）によ るエネルギー計算は，96コア（Xeon $3.0 \mathrm{GHz})$ パ ソコンクラスターで約 10 時間である（GAMESS による計算).

\section{5. おわりに}

本稿で紹介した FMO 法をはじめとする大規模分 子系の量子化学法の発展によりタンパク質全系を量 子論的に計算することが可能となってきた。しか し，創薬研究では，バーチャルスクリーニングから リード化合物の最適化まで，それぞれの研究段階で 高速から高精度までいろいろな計算手法を使い分け る必要がある。FMO 法は最も高精度な計算法とし て，タンパク質とリガンドの相互作用解析に用いら れている. ${ }^{13,14)}$ 一方，分子間相互作用を精密に解析 するには構造データの精度が高いことが前提とな る。高解像度の X 線構造が存在する場合は，それ 
にもとづいて構造モデルを作成し FMO 法でエネル ギーの計算を行えばよいが，実験構造の解像度が低 い場合，または実験構造が存在せずドッキングシミ ユレーションで予測されたモデル構造の場合，構造 最適化計算により一定の精度を持つた構造デー夕を 準備する必要がある.

これまで構造最適化はほとんど MM 計算で行わ れてきた。これを量子化学計算で行うことにより信 頼性の高い構造モデルが得られると期待される（金 属原子を含む場合はもとより, $\mathrm{CH} / \pi$ やハロゲン/ $\pi$ などの非結合相互作用は MM では適切に評価で きないことが多い)。FMO 法で構造最適化計算を 行うことは可能であるが，多数の複合体の構造を求 めるのは計算時間から考えて当面は現実的でない.

私たちは，FMO 法に順次近似を導入することによ り計算時間を短縮できるいくつかの方法を開発して いる．MM との融合法 $(\mathrm{FMO} / \mathrm{MM} \text { 法 })^{15)}$ は系の重 要部分（リガンドと近接アミノ酸残基など）を FMO 法で，その他の部分は MM で計算する方法で ある。.また，系の重要部分のみについて部分構造最 適化を行うときには，frozen domain FMO 法 $(\mathrm{FMO} / \mathrm{FD} \text { 法 })^{16)}$ を用いて，全系 FMO 計算に比較 して格段に高速な計算ができる。これらにより構造 最適化計算を実用的な時間で行うことができるとと もに，タンパク質とリガンドの相互作用をおおむね FMO 法に近い精度で解析することができる.

結合自由エネルギーの高精度予測を可能にするた めには，溶媒和エネルギーの高精度評価法が必要で ある。私たちは溶媒の連続体モデルとして量子化学 計算でよく用いられている Polarizable continuum model（PCM）とFMO 法を組み合わせた方法 $(\mathrm{FMO} / \mathrm{PCM} \text { 法 })^{17)}$ を開発し，タンパク質ーリガンド 複合体のような巨大分子系の計算を可能とした。し かし，タンパク質のリガンド結合サイトで強く結合 された水分子や結合ポケット中で構造化された水分 子のエネルギーを連続体モデルで適切に評価するの は困難であることは明らかであり，新しい溶媒和エ ネルギー計算法の出現が待たれる.

\section{REFERENCES}

1) Zhou T., Huang H., Caflisch A., Curr. Top. Med. Chem., 10, 33-45 (2010).
2) Fedorov D. G., Kitaura K., "'Modern Methods for Theoretical Physical Chemistry and Biopolymers," Chap. 1, eds. by Starikov E. B., Lewis J. P., Tanaka S., Elsevier, Amsterdam, 2006, pp. 3-38.

3) Fedorov D. G., Kitaura K., J. Phys. Chem. A, 111, 6904-6914 (2007).

4) Nakanishi I., Fedorov D. G., Kitaura K., Proteins: Struct. Funct. Bioinf., 68, 145-158 (2007) .

5) Fedorov D. G., Kitaura K., J. Comp. Chem., 28, 222-237 (2007).

6) Sitkoff D., Sharp K. A., Honig B., J. Phys. Chem., 98, 1978-1988 (1994).

7) Discove Studio and Insight II, Accelrys Software Inc., San Diego, CA.

8) Holt D. A., Luengo J. I., Yamashita D. S., Oh H.-J., Konialian A. L., Yen H.-K., Rozamus L. W., Brandt M., Bossard M. J., Levy M. A., Eggleston D. S., Liang J., Schultz L. W., Stout T. J., Clardy J., J. Am. Chem. Soc., 115, 9925-9938 (1993).

9) GAMESS. 〈http://www.msg.chem.iastate.edu /gamess/>, cited 10 June, 2011.

10) ABINIT-MP and BioStation Viewer. 〈http:// www.ciss.iis.u-tokyo.ac.jp/rss21/result/down load/index.php\#download_2 $\rangle$, cited 10 June, 2011.

11) PAICS and Paics View. 〈http://www.paics. net/link.html $\rangle$, cited 10 June, 2011.

12) Facio. 〈http://www1.bbiq.jp/zzzfelis/Facio_ Jp.html $\rangle$, cited 10 June, 2011.

13) “The Fragment Molecular Orbital Method: Practical Applications to Large Molecular Systems," eds. by Fedorov D. G., Kitaura K., CRC Press, Boca Raton, 2009.

14) Mazanetz M. P., Ichihara O., Law R. J., Whittaker M., J. Cheminfomatics, doi: 10.1186/1758-2946-3-2 (2011).

15) Fedorov D. G., Ishida T., Uebayasi M., Kitaura K., J. Phys. Chem. A, 111, 2722-2732 (2007).

16) Fedorov D. G., Kitaura K., J. Phys. Chem. Lett., 2, 282-288 (2011).

17) Fedorov D. G., Kitaura K., Li H., Jensen J. H., Gordon M. S., J. Comp. Chem., 27, 976985 (2006). 